\title{
Effect of Some Soil Amendments on The mobility of Some Heavy Metal ions in a Contaminated Soil
}

Ahmed, H. A. ; T. M. Mosalem; Abd-El hady, E.S. and A. SH. Abdel-fattah

Soils and Water Dept., Fac. of Agric. Al- Azhar University

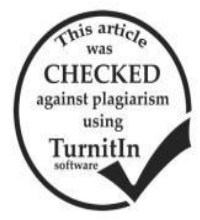

\section{ABSTRACT}

An outdoor pot experiment was carried out at the farm of Agriculture Faculty, Al -Azahr University during the winter season of 2015, to study the efficiency of some amendments (palm waste, gypsum and rock phosphate) on the mobility of $\mathrm{Fe}^{2+}$, $\mathrm{Zn}^{2+}, \mathrm{Mn}^{2+}, \mathrm{Cu}^{2+}, \mathrm{Cd}^{2+}$ and $\mathrm{Pb}^{2+}$. A composite surface soil sample $(0-30 \mathrm{~cm})$ was collected from south west of Port Said City. The experiment involved 33 pots comprised 11 treatments with three replicates in a completely randomized design. Plastic pots are used of $18 \mathrm{~cm}$ inside diameter $22 \mathrm{~cm}$ depth and each contains $2.0 \mathrm{~kg}$ dry soil. The soils were well mixed with gypsum and rock phosphate applied at the rates 4,6 and 8 ton $\mathrm{fd}^{-1}$ while the soils were well mixed with (palm waste) applied at the rate 5 ton $\mathrm{fd}^{-1}$ for all treatments, and then incubated for 60 days in three replicates, beside the untreated soil (control). During soil incubation the moisture content of the pots was kept at the water field capacity, then-at the end of the period of incubation the soil samples were analyzed for some physical and chemical properties, and content of the heavy metals under investigation $\left(\mathrm{Fe}^{2+}, \mathrm{Zn}^{2+}, \mathrm{Mn}^{2+}, \mathrm{Cu}^{2+}\right.$, $\mathrm{Cd}^{2+}$ and $\mathrm{Pb}^{2+}$ ). The most important results obtained could be summarized as follows :1- In all treatments pH and ESP values were decreased compared with the control.2-Organic matter, cation exchange capacity, and active calcium carbonate values in the studies soil were increased with increasing the addition of the treatments compared with the control, while bulk density tended to be lower 3-Heavy metal mobility decreased When mixing all of (palm waste, agricultural gypsum and rock phosphate) Generally the results showed the importance of using some amendments such as palm waste, agricultural gypsum and rock phosphate in reducing the mobility of heavy metals $\left(\mathrm{Fe}^{2+}, \mathrm{Zn}^{2+}, \mathrm{Mn}^{2+}, \mathrm{Cu}^{2+}, \mathrm{Cd}^{2+}\right.$ and $\left.\mathrm{Pb}^{2+}\right)$ in contaminated soils.

Keywords: Palm waste, gypsum, rock phosphate, heavy metals and contaminated soil

\section{INTRODUCTION}

New agricultural land projects require substantial amounts of water that can only be found through reuse of drainage water and treated waste water. But when water containing some of heavy metals as pollutants used as irrigation water, soils and crops will be contaminated and enriched with such toxic metals. The potential problems due to the use of wastewater on cropland include contamination of surface and ground water, and the entering of toxic heavy metals into the food chain,(Belkhiri et al,2010). Continuous monitoring of the heavy metal accumulation in the environment must be applied to avoid health risk and further deterioration of the environment. the exact reaction mechanism responsible for the removal of metal ions by rock phosphate/apatite is still unknown., but the sorption process, which generally involves species attachment from a solution to its co-existing solid surface by three types, namely surface adsorption, absorption or diffusion into the solid and precipitation or coprecipitation appears to be the governing mechanism for the retention of metal ions by rock phosphate. As observed, in all palm waste treatments with passage of time, the amount of heavy metals of leachate was decreased,(Asadi et al, 2008).

Increasing the rate of date palm waste increased nitrate in soil columns and reduced the nitrate in leachate,(Al-Shaikh et al, 2009). Abdel-fattah, (2012) reported that application of gypsum combined with water hyacinth compost or rice straw compost enhanced reclamation and caused more decreases in salinity as well acidity .The mechanisms involved in $\mathrm{P}$-induced $\mathrm{Pb}$ immobilization include ionic exchange and chemical precipitation, Suzuki et al (1984). The immobilization of metals in soils for plant uptake and leaching to groundwater can, however, be minimized by reducing the bioavailability of metals through chemical and biological mobilization. Recently, there has been increasing interest in the immobilization of metals using a range of inorganic compounds, such as lime, phosphate (P) compounds (e.g., apatite rocks), and alkaline waste materials, and organic compounds, such as exceptional quality bio solids,(Basta et al ,2001 and Knox et al, 2000). Soil organic matter has an essential function in the accumulation and transport of metals as well as in delaying their circulation in the soil. Therefore, the toxicity of metals may be both increased as well as decreased by organic substances under specific environmental conditions (Malak ,1995).Reuse the date palm waste led to increase the fertilizers use efficiency and reduce the problems of ground water pollution. As observed, in all palm treatments with passage of time, the amount of heavy metals of leachate was decreased and the highest reduction was also related to 1-2 cm palm treatment, ( Asadi et al ,2008). There for ,this investigation aims to study efficiency of some amendments (palm waste, gypsum and rock phosphate) on the mobility of $\mathrm{Fe}^{2+}, \mathrm{Zn}^{2+}, \mathrm{Mn}^{2+}, \mathrm{Cu}^{2+}, \mathrm{Cd}^{2+}$ and $\mathrm{Pb}^{2+}$. Composite surface soil sample $(0-30 \mathrm{~cm})$ was collected from south west of Port Said City.

\section{MATERIALS AND METHODS}

\section{Location of the studied area}

A represented composite soil sample was collected from north-east of Nile Delta, southwest of Port Said City (Fig.1). The soils of this area are irrigated with fresh Nile water mixed with drainage water of ElSerw and Bahr Hadous drain from El-Salam canal.

An outdoor pot experiment was carried out in the farm of Agriculture Faculty, Al-Azahr University during the winter season of 2015 , to study the efficiency of some soil amendments (palm waste, gypsum and rock phosphate) on heavy metal ions mobility.

The experiment involved 33 pots comprised 11 treatments with three replicates in a completely randomized design. Plastic pots are used of $18 \mathrm{~cm}$ inside 
diameter $22 \mathrm{~cm}$ depth and each contains $2.0 \mathrm{~kg}$ soil. The soils were well mixed with gypsum and rock phosphate particles (of particles size $<0.08 \mathrm{~mm}$ ), applied at rates 4 , 6 and 8 ton $\mathrm{fd}^{-1}$ while the soils was well mixed with (palm waste) at less than $0.8 \mathrm{~mm}$ diameter, applied at rate 5 ton $\mathrm{fd}^{-1}$ for the all treatments, then incubated for 60 days in three replicates, beside the untreated soil (control).

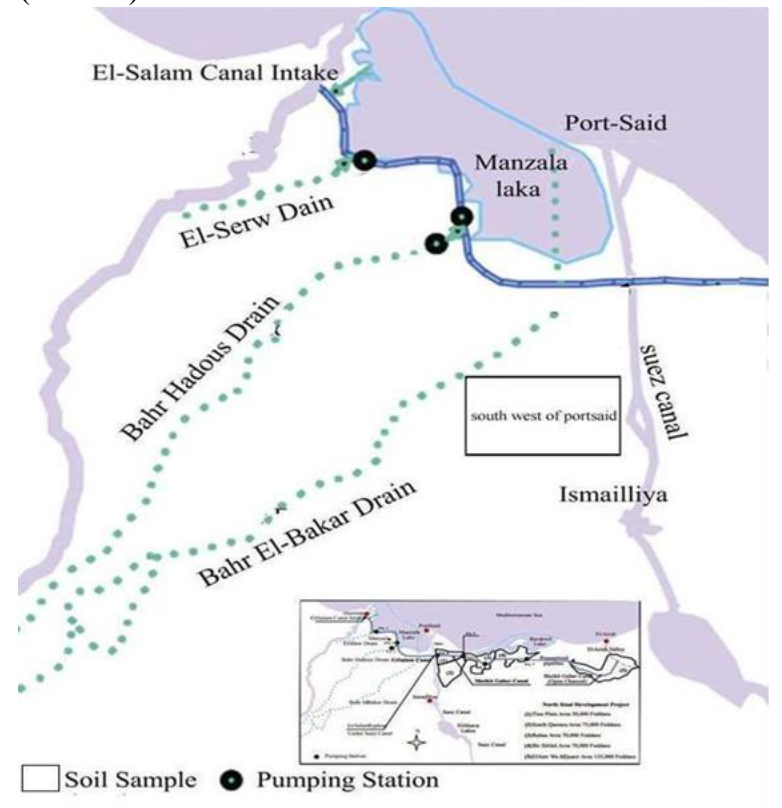

Fig. 1. Schematic map of the studied area

During soil incubation the moisture content of the pots was kept at the water field capacity, the treatments were as follows:

1- Soil (control), without any amendments

2- Soil mixed with palm waste at the rate of 5 ton $\mathrm{fd}^{-1}$.

3- Soil mixed with palm waste, and gypsum at the rates of 5 and 4 ton $\mathrm{fd}^{-1}$, respectively.

4-Soil mixed with palm waste, and gypsum at the rates of 5 and 6 ton $\mathrm{fd}^{-1}$, respectively.

5-Soil mixed with palm waste, and gypsum at rates of 5 and 8 ton $\mathrm{fd}^{-1}$, respectively.

6-Soil mixed with palm waste, and rock phosphate at rates of 5 and 4 ton $\mathrm{fd}^{-1}$, respectively.

7-Soil mixed with palm waste, and rock phosphate rates of 5 and 6 ton $\mathrm{fd}^{-1}$, respectively.

8-Soil mixed with palm waste, and rock phosphate at the rates of 5 and 8 ton $\mathrm{fd}^{-1}$, respectively.

9-Contaminated soil mixed with palm waste, gypsum and rock phosphate at the rates of 5,2 and 2 ton $\mathrm{fd}^{-1}$, respectively.

10-Soil mixed with palm waste, gypsum and rock phosphate at the rates of 5,3 and 3 ton $\mathrm{fd}^{-1}$, respectively.

11-Soil mixed with palm waste, gypsum and rock phosphate at the rates of 5,4 and 4 ton $\mathrm{fd}^{-1}$, respectively.

Then after, at the end of the period of soil incubation some physical and chemical analysis were carried out according to the standard methods undertaken by (Klute 1986) and (Page et. al., 1982). Also, extractable ions $\left(\mathrm{Fe}^{2+}, \mathrm{Zn}^{2+}, \mathrm{Mn}^{2+}, \mathrm{Cu}^{2+}, \mathrm{Cd}^{2+}\right.$ and $\left.\mathrm{Pb}^{2+}\right)$ were determined in the soil using ammonium
bicarbonate-DTPA extractable according to (Soltanpour and Schwab 1977), and their contents in the obtained extract were measured by atomic absorption spectrophotometer. Some physical and chemical analyses of the used amendments rock phosphate, gypsum and palm waste are presented in Table 1.

Table 1. Some physical and chemical analyses of the used amendments rock phosphate, gypsum and palm waste:

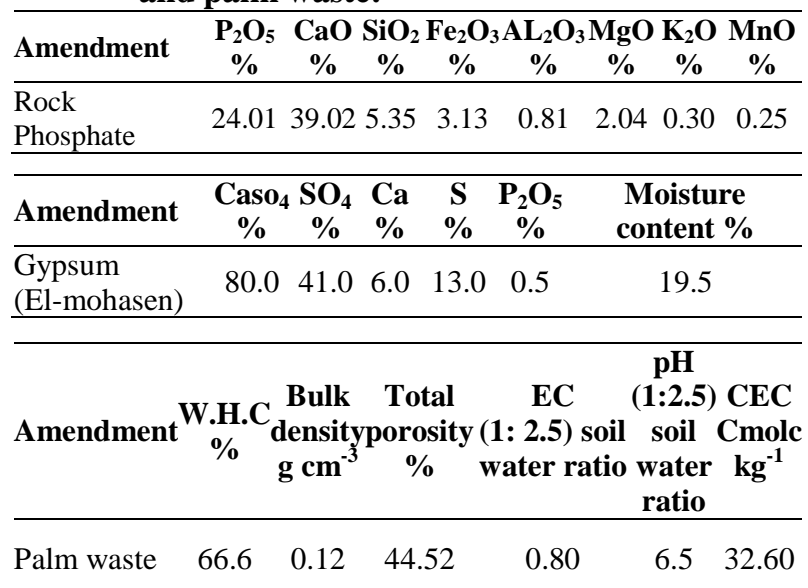

\section{Statistical analysis:}

The collected data were subjected to the proper statistical analysis of complete randomized block design combined over locations according to (Steel and Torrie 1980), Using LSD at 1 and $5 \%$ level.

\section{RESULTS AND DISCUSSION}

Soil sample characteristics before incubation:

The physical and chemical characteristics of the studied soil sample are shown in Table 2.

Table 2. Some physical and chemical characteristics of studied soil sample before incubation.

\begin{tabular}{|c|c|c|c|}
\hline \multirow{2}{*}{$\begin{array}{l}\text { Value } \\
\text { The physical properties }\end{array}$} & \multicolumn{3}{|c|}{ Parameter } \\
\hline & \\
\hline$\%$ Sand & & 32.47 & \\
\hline$\%$ Silt & & 14.75 & \\
\hline$\%$ Clay & & 52.78 & \\
\hline Textural class & & Clay & \\
\hline Bulk density $\mathrm{g} \mathrm{cm}^{-3}$ & & 1.47 & \\
\hline Total porosity \% & & 44.52 & \\
\hline Hydraulic conductivity $\left(\mathrm{cm} \mathrm{h}^{-1}\right)$ & & 1.56 & \\
\hline \multicolumn{4}{|l|}{ The chemical properties } \\
\hline $\mathrm{pH}(1: 2.5$ soil suspension $)$ & & 8.3 & \\
\hline EC(1:2.5 soil water ratio $) \mathrm{dSm}^{-1}$ & & 2.90 & \\
\hline O.M \% & & 1.30 & \\
\hline$\% \mathrm{CaCO}_{3}$ & & 5.8 & \\
\hline$\%$ Active $\mathrm{CaCo}^{3}$ & & 0.89 & \\
\hline CEC (cmolc kg-1) & & 40.60 & \\
\hline Exchangeable $\mathrm{Na}^{+1}\left(\mathrm{cmolc} \mathrm{kg}^{-1}\right)$ & & 7.34 & \\
\hline ESP \% & & 18.70 & \\
\hline GR & & 12 ton $\mathrm{fd}^{-1}$ & \\
\hline \multicolumn{4}{|c|}{ Soluble cations and anions $\left(\mathrm{mmol}_{\mathrm{c}} \mathrm{L}^{-1}\right)$ and NPK } \\
\hline $\mathrm{Ca}^{2+} \quad 4.2 \quad \mathrm{CO}_{3}{ }^{2-}$ & ND & $\% \mathrm{~N}$ & 1.50 \\
\hline $\mathrm{HCO}_{3}{ }^{1-}$ & 1.9 & $\% \mathrm{P}$ & 1.40 \\
\hline $\mathrm{Cl}^{1-}$ & 17.8 & & \\
\hline $\mathrm{SO}_{4}^{2-}$ & 11.50 & $\% \mathrm{~K}$ & 0.18 \\
\hline \multicolumn{4}{|c|}{ Available heavy metals : $\left(\mathrm{mg} \mathrm{kg}^{-1}\right)$} \\
\hline $\mathrm{Fe}^{2+}$ & & 73.7 & \\
\hline $\mathrm{Zn}^{2+}$ & & 1.28 & \\
\hline $\mathrm{Mn}^{2+}$ & & 4.94 & \\
\hline $\mathrm{Cu}^{2+}$ & & 2.58 & \\
\hline $\mathrm{Cd}^{2+}$ & & 1.76 & \\
\hline $\mathrm{Pb}^{2+}$ & & 11.75 & \\
\hline
\end{tabular}


The soil sample was clayey of $\mathrm{pH} 8.3$, the total measured carbonate as calcium carbonate was $5.8 \%$, while the active calcium was about $0.89 \%$. The organic matter content was low as $1.3 \%$, as well as low water soluble salts (EC $2.9 \mathrm{dSm}^{-1}$ ).

The cation exchange capacity value reached 40.6 cmol kg-1 mainly due to the high clay fraction content 52.78\%.Moreover,the soil sample had high exchangeable sodium percentage $(\mathrm{ESP}=18.7 \%)$, indicating sodic soil type.

Effect of the different amendments on mobility of $\mathrm{Fe}^{2+}, \mathrm{Zn}^{2+}, \mathrm{Mn}^{2+}, \mathrm{Cu}^{2+}, \mathrm{Cd}^{2+}$ and $\mathrm{Pb}^{2+}$ in the soils.

Data in Table 3 and 4 represent the mobility and mobility $\%$ of the control of $\left(\mathrm{Fe} 2^{+}, \mathrm{Zn}^{2+}, \mathrm{Mn}^{2+}, \mathrm{Cu}^{2+}\right.$, $\mathrm{Cd}^{2+}$ and $\mathrm{Pb}^{2+}$ as affected by different amendments(palm waste, gypsum, and rock phosphate) after 60 days of incubation at rates of 4, 6 and 8 tonfd $^{-1}$ respectively and 5 ton $\mathrm{fd}^{-1}$ palm west for all treatments. The results show that the amounts of mobile $\mathrm{Fe}^{2+}, \mathrm{Zn}^{2+}$, $\mathrm{Mn}^{2+}, \mathrm{Cu}^{2+}, \mathrm{Cd}^{2+}$ and $\mathrm{Pb}^{2+}$ were reduced after the incubation period and the reduction increased with increasing rates of applied amendments(palm waste, gypsum and rock phosphate) compared with the control (untreated soil).

Table. 3. Mobility of $\mathrm{Fe}^{2+}, \mathrm{Zn}^{2+}, \mathrm{Mn}^{2+}, \mathrm{Cu}^{2+}, \mathrm{Cd}^{2+}$ and $\mathrm{Pb}^{2+}$ in soil after incubation soil

\begin{tabular}{|c|c|c|c|c|c|c|}
\hline \multirow{2}{*}{$\begin{array}{l}\text { No } \\
\text { Treatments }\end{array}$} & \multirow[b]{2}{*}{$\mathrm{Fe}^{2+}$} & \multicolumn{4}{|c|}{ Mobility (mg kg ${ }^{-1}$ ) } & \multirow[b]{2}{*}{$\mathbf{P b}^{2+}$} \\
\hline & & $\mathrm{Zn}^{2+}$ & $\mathrm{Mn}^{2+}$ & $\mathrm{Cu}^{2+}$ & $\mathrm{Cd}^{2+}$ & \\
\hline 1 & 73.7 & 1.28 & 4.91 & 2.58 & 1.76 & 11.75 \\
\hline 2 & 65.7 & 1.25 & 3.50 & 1.98 & 1.57 & 9.20 \\
\hline 3 & 64.9 & 1.24 & 2.22 & 2.50 & 1.54 & 9.42 \\
\hline 4 & 55.8 & 1.23 & 2.09 & 2.25 & 1.31 & 9.31 \\
\hline 5 & 55.7 & 1.13 & 2.03 & 2.23 & 1.30 & 9.12 \\
\hline 6 & 57.9 & 0.90 & 2.44 & 1.39 & 1.20 & 8.70 \\
\hline 7 & 48.3 & 0.83 & 2.44 & 1.37 & 1.19 & 7.75 \\
\hline 8 & 48.3 & 0.83 & 2.32 & 1.35 & 1.17 & 7.61 \\
\hline 9 & 51.6 & 1.22 & 2.91 & 1.41 & 1.49 & 6.32 \\
\hline 10 & 51.3 & 1.10 & 2.90 & 1.50 & 1.41 & 6.22 \\
\hline 11 & 50.5 & 1.08 & 2.90 & 1.50 & 1.32 & 6.11 \\
\hline L.S.D. $5 \%$ & 0.16 & 2.69 & 0.08 & 0.08 & 0.07 & 0.07 \\
\hline L.S.D. $1 \%$ & 0.23 & 3.6 & 0.12 & 0.12 & 0.10 & 0.10 \\
\hline
\end{tabular}

Using both rock phosphate and agricultural gypsum with different rates in each other incubated experiment were confirmed a significant reduction in heavy elements after a period of incubation about 60 days this probably due to the role of both gypsum and mineral apatite that can be interpreted as provide a source of calcium, which exchange with heavy metals ions and some other elements, such as sodium ,moreover, there is a relationship between the element phosphorus and some heavy metals which was confirmed by some researchers and consequently the deposition of heavy elements processes that may occur in the soil and may take different forms,(Abdel-fattah, 2012).

Thus the element phosphorus is likely and certainly converts part of the forms of heavy metals in abundance in this contaminated soil to complexes and become a semi/ or immobile or to minimize the mobility of pollutants into the soil. This could emphasize the important role of (gypsum, rock phosphate) to retain heavy meta lions in soil as immobile form(Chenet. al,. 2006). The effect of granular size of rock phosphate on the effectiveness of heavy metal ions immobilization in two contaminated soils was measured in pot experiment. Gypsum has been reevaluated in the light of recent finding on its effect on soil physical and chemical properties.

The exact reaction mechanism responsible for the removal of metal ions by rock phosphate/apatite is still unknown., but the sorption process, which generally involves species attachment from a solution to its coexisting solid surface by three types, namely surface adsorption, absorption or diffusion into the solid and precipitation or co -precipitation appears to be the governing mechanism for the retention of metal ions by rock phosphate,(Saxena, and Souza, 2005).

It has been shown that the primary mechanism of metal ion removal by rock phosphate is governed by its dissolution in acidic environment followed by subsequent precipitation, recent evidences supports the removal to be governed by dissolution- precipitation mechanism. Hence, the process may be reduced to a generalized sorption process. In addition to the above hypothesis, where $\mathrm{P}$ in the form of $\mathrm{H}_{2} \mathrm{PO}_{4}{ }^{-}$helps in precipitating metal ions in aqueous solutions, the possibility of exchange of $\mathrm{Ca}^{2+}$ by metal ions cannot be ruled out. It may be interpreted that the dissolution of apatite also provides $\mathrm{Ca}$, which exchanges with the aqueous metal leading to the precipitation of corresponding mineral phase.

The results show also that the available amounts of $\mathrm{Fe}^{2+}, \mathrm{Zn}^{2+}, \mathrm{Mn}^{2+}, \mathrm{Cu}^{2+}, \mathrm{Cd}^{2+}$ and $\mathrm{Pb}^{2+}$ were reduced after incubation of applied amendments(palm waste) compared with the control (untreated soil).

Many researchers confirmed that (palm waste) as an organic matter, can affect soil physical and chemical properties. Due to its exchange capacity and buffering capacity, it can play an essential role in controlling and immobilizing large amounts of heavy metals in the soil.

Generally the results showed the importance of using some of amendments such as( palm waste, gypsum and rock phosphate) for such soil at the rates5, 4 , and 4 ton $\mathrm{fd}^{-1}$ in reducing the mobility of heavy metals ions of $\mathrm{Fe}^{2+}, \mathrm{Zn}^{2+}, \mathrm{Mn}^{2+}, \mathrm{Cu}^{2+}, \mathrm{Cd}^{2+}$ and $\mathrm{Pb}^{2+}$ in contaminated soil.

Table 4. Mobility $\%$ of the native $\mathrm{Fe}^{2+}, \mathrm{Zn}^{2+}, \mathrm{Mn}^{2+}$, $\mathrm{Cu}^{2+}, \mathrm{Cd}^{2+}$ and $\mathrm{Pb}^{2+}$ in soil after incubation

\begin{tabular}{|c|c|c|c|c|c|c|}
\hline \multirow{2}{*}{$\begin{array}{l}\text { No } \\
\text { Treatments }\end{array}$} & \multicolumn{6}{|c|}{ Mobility \% of the native heavy metals } \\
\hline & $\mathrm{Fe}^{2+}$ & $\mathbf{Z n}^{2+}$ & $\mathrm{Mn}^{2+}$ & $\mathbf{C u}^{2+}$ & $\mathbf{C d}^{2+}$ & $\mathbf{P b}^{2+}$ \\
\hline 1 & 100 & 100 & 100 & 100 & 100 & 100 \\
\hline 2 & 89.14 & 97.65 & 71.28 & 76.74 & 89.20 & 78.29 \\
\hline 3 & 99.88 & 96.87 & 45.21 & 96.89 & 87.50 & 80.17 \\
\hline 4 & 75.71 & 96.07 & 42.56 & 87.20 & 74.43 & 79.23 \\
\hline 5 & 75.57 & 88.28 & 41.34 & 86.43 & 73.86 & 77.61 \\
\hline 6 & 78.56 & 70.31 & 49.69 & 53.87 & 68.18 & 74.04 \\
\hline 7 & 65.53 & 64.84 & 49.69 & 53.10 & 67.61 & 65.95 \\
\hline 8 & 65.53 & 64.84 & 47.25 & 52.32 & 66.47 & 64.76 \\
\hline 9 & 70.01 & 95.31 & 59.26 & 54.65 & 84.65 & 53.78 \\
\hline 10 & 69.60 & 85.93 & 59.06 & 58.13 & 80.11 & 52.93 \\
\hline 11 & 68.52 & 84.37 & 59.06 & 58.13 & 75.00 & 52.00 \\
\hline L.S.D. 5\% & 0.07 & 0.05 & 0.05 & 0.08 & 1.5 & 1.4 \\
\hline L.S.D. $1 \%$ & 0.10 & 0.07 & 0.07 & 0.12 & 2.06 & 2.01 \\
\hline
\end{tabular}

Exchangeable cations $\left(\mathrm{cmol} \mathrm{kg}^{-1)}\right.$ in soil after incubation

Data in Table 5 show that the ESP of the soils under study were significantly reduced with of incubation after 60 days as well as with increasing rates of applied amendments of (palm waste, gypsum and 
rock phosphate)5, 4 and 4 ton $\mathrm{fd}^{-1}$ respectively, compared with the control (untreated soil).These led to an improvement in physical and chemical properties of soils and thereby increase productivity.

The results also illustrated the role of the organic material of the palm waste to improve and reduce the soil content of exchangeable sodium. This is probably because the content of complex material and that exchange with sodium limiting of riskiness in sodic soil and thus improve the physical, chemical and nutritional properties.

Table 5. Exchangeable cations $\left(\mathrm{cmolckg}^{-1}\right)$ in soil after incubation

\begin{tabular}{|c|c|c|c|c|c|}
\hline \multirow{2}{*}{$\begin{array}{l}\text { No } \\
\text { Treatments }\end{array}$} & \multicolumn{4}{|c|}{ Exchangeable cation } & \multirow{2}{*}{$\begin{array}{c}\text { ESP } \\
\%\end{array}$} \\
\hline & $\mathrm{Ca}^{2+}$ & $\mathrm{Mg}^{2+}$ & $\mathrm{Na}^{1+}$ & $\mathbf{K}^{1+}$ & \\
\hline 1 & 13.7 & 13.7 & 7.3 & 4.4 & 18.70 \\
\hline 2 & 17.4 & 11.4 & 6.0 & 3.5 & 15.58 \\
\hline 3 & 16.5 & 12.5 & 6.4 & 3.5 & 16.45 \\
\hline 4 & 17.5 & 11.3 & 6.0 & 3.5 & 15.58 \\
\hline 5 & 19.3 & 10.1 & 5.2 & 3.6 & 13.61 \\
\hline 6 & 18.9 & 10.2 & 5.1 & 3.6 & 13.49 \\
\hline 7 & 18.9 & 10.7 & 5.0 & 3.8 & 13.02 \\
\hline 8 & 18.8 & 10.6 & 4.7 & 3.6 & 12.46 \\
\hline 9 & 21.7 & 9.7 & 4.5 & 3.6 & 11.39 \\
\hline 10 & 22.6 & 9.8 & 4.4 & 3.7 & 10.86 \\
\hline 11 & 22.8 & 9.9 & 4.3 & 3.8 & 10.53 \\
\hline L.S.D. $5 \%$ & 0.16 & 0.16 & 0.16 & 0.16 & 0.05 \\
\hline L.S.D. $1 \%$ & 0.23 & 0.23 & 0.23 & 0.23 & 0.07 \\
\hline
\end{tabular}

The influence of the soil amendments on bulk density and total porosity:

It is well known that soil porosity is a function of bulk density; therefore data of total porosity follows the opposite trend of bulk density. Soil bulk density and total porosity play an important role in the further use of farm management, machinery and crop growth and yield. Hence the relationship between soil compaction and soil bulk density changes must be taken into account. Table 6 show that the mean values of bulk densities and total porosities for the soils under study as affected by different amendments(palm waste, gypsum and rock phosphate) after 60 days of incubation at rates of5, 4 and 4 ton $\mathrm{fd}^{-1}$ per treatments, respectively. The results show that the mean values of bulk densities for the soils under study were significantly reduced with incubation after 60 days as well as with increasing rates of applied different amendments (palm waste, gypsum and rock phosphate) compared with the control (untreated soil). On the other hand the total porosities increased with the application of different amendments(palm waste, gypsum, and rock phosphate) compared with the control (untreated soil).This could be attributed to the application of applied different amendments which had affected pore size distribution and improving the physical soil properties of the investigated treatments. Soil bulk density decreased while total porosity increased gradually with application of different amendments.

High bulk density of $1.57 \mathrm{~g} \mathrm{~cm}^{-3}$ probably is due to the presence of dust in this size and during chopping and separating the different sizes of palm wastes .Palm wastes as abed especially palm, due to lignin exist in it, led to the increase of bulk density,(Abdel Aziz et al ,1998) .
Total porosity and air porosity were more in large particles that are due to less bulk density and making larger porosities, (Ravivetal,2001).Bulk density is inversely related to total porosity, (Baig et al,1999).

The influence of active $\mathrm{CaCO}_{3}$ on the studied soils

The data presented in Table 6 show that the influence of the applied different amendments on active $\mathrm{CaCO}_{3}$ values comparing to the value of the control.

Total soil calcium carbonate values determined as active calcium carbonate $(\%)$ are presented in Table 6 the results show that the highest active calcium carbonate mean values were $2.24 \%$ and 2.29 for the treatment of rock phosphate and gypsum while the lowest active calcium carbonate mean values were 1.5 and $1.7 \%$ for the treatment of rock phosphate.

This increase of the active calcium carbonate may help reduce the risk of soil contamination through increasing adsorption on the active surfaces of the soil under study and this agreed with Mourid, (2014) who proved that the total content of $\mathrm{CaCO}_{3}$ is not the limiting factor in the adsorption and retention processes but the active $\mathrm{CaCO}_{3}$ fraction and the clay contents are more effective.

\section{The influence on cation exchange capacity CEC of} the studied soils

Results presented in Table 6 generally reveal that the addition of the used treatments increased CEC values relative to the initial state.

It can be concluded that the increase of CEC values may be due to the effect of adding palm waste.

\section{Soil reaction $\mathbf{p H}$}

Data reported in Table 6 show that the mean $\mathrm{pH}$ values of soils treated by (palm waste, gypsum and rock phosphate) compared with the control. The application of the investigated treatments as separated or combined decreased soil $\mathrm{pH}$ values, for all treatments from 8.3 to 7.8 compared with the control.

The decrease in soil $\mathrm{pH}$ was probably due to combination of more than one factor, mainly the replacement of sodium by calcium and the formation of neutral salts with $\mathrm{SO}_{4}{ }^{2-}$. The decrease in soil $\mathrm{pH}$ may also due to the decrease in sodium concentration as a fraction of the exchangeable cations. This interpretation is in agreement with that observed by Abdel-fattah, (2012). He pointed out that application of gypsum combined with water hyacinth compost or rice straw compost enhanced reclamation and caused more decrease in salinity as well as soil pH. Suarez, and Griee, (1984).showed that sodic soils contain exchangeable sodium ions on soil colloids as well as soluble carbonates in the form of $\mathrm{Na}_{2} \mathrm{CO}_{3}$ and $\mathrm{NaHCO}_{3}$, they are responsible for the high $\mathrm{pH}(>8.4)$ of the soil, clay dispersion, soil swelling, and overall poor soil .

The process that replaces exchangeable $\mathrm{Na}^{1+}$ on soil colloids with $\mathrm{Ca}^{2+}$ is very important in alkali soil reclamation. This replacement causes flocculation of soil particles and results in improved soil permeability. The release of $\mathrm{Ca}^{2+}$ from $\mathrm{CaCO}_{3}$ in naturally existing soil is not effective for inducing the exchange reaction because of the low solubility of $\mathrm{CaCO}_{3}$ at high $\mathrm{pH}$ values,(Gupta, and Abrol, 1990). 
Table 6. some physical and chemical characteristics in soilsafter incubation

\begin{tabular}{|c|c|c|c|c|c|c|c|}
\hline No Treatments & $\begin{array}{c}\text { Total porosity } \\
\% \\
\end{array}$ & $\begin{array}{c}\text { CEC } \\
\left(\mathrm{Cmolc} \mathrm{kg}^{-1}\right)\end{array}$ & $\begin{array}{c}\text { Active } \mathrm{CaCo}_{3} \\
\% \\
\end{array}$ & $\begin{array}{c}\text { Bulk density } \\
\mathrm{g} \mathrm{cm}^{3}\end{array}$ & $\begin{array}{c}\text { OM } \\
\%\end{array}$ & $\begin{array}{c}\text { pH } \\
(1: 2.5)\end{array}$ & $\begin{array}{c}\mathrm{EC} \\
\mathrm{dSm}^{-1}\end{array}$ \\
\hline$\overline{1}$ & 44.52 & 40.6 & 0.89 & 1.47 & 1.30 & 8.3 & 2.90 \\
\hline 2 & 42.26 & 41.8 & 1.10 & 1.53 & 2.19 & 7.5 & 2.91 \\
\hline 3 & 45.28 & 41.7 & 1.50 & 1.45 & 1.60 & 8.2 & 2.89 \\
\hline 4 & 45.66 & 41.8 & 1.69 & $1 . .44$ & 2.00 & 8.1 & 2.91 \\
\hline 5 & 45.66 & 41.8 & 1.71 & 1.44 & 2.10 & 7.9 & 3.21 \\
\hline 6 & 45.28 & 41.8 & 1.51 & 1.45 & 2.00 & 8.0 & 2.92 \\
\hline 7 & 45.03 & 41.8 & 1.70 & 1.43 & 2.10 & 8.2 & 2.43 \\
\hline 8 & 46.41 & 41.8 & 2.00 & 1.42 & 2.11 & 7.9 & 3.00 \\
\hline 9 & 45.66 & 41.9 & 1.52 & 1.44 & 2.11 & 8.2 & 2.91 \\
\hline 10 & 46.79 & 41.9 & 2.24 & 1.41 & 2.21 & 7.8 & 2.90 \\
\hline 11 & 47.54 & 41.9 & 2.29 & 1.39 & 2.21 & 7.8 & 3.11 \\
\hline L.S.D. $5 \%$ & 0.12 & 0.016 & 0.10 & 0.01 & 0.12 & 0.16 & 0.11 \\
\hline L.S.D. $1 \%$ & 0.16 & 0.23 & 0.13 & 0.02 & 0.17 & 0.23 & 0.19 \\
\hline
\end{tabular}

\section{REFERENCES}

Abdel Aziz,M.S ; F.S. Salem; M.M.A. Reda and L.A. Hussien ,. (1998): Influence of some amendments on the clayey soil properties and crop production. Fayoum .J. Agric. Res \& Dev. , 12 (1):196-204.

Abdel-fattah, Mohamed K. (2012): Role of gypsum and compost in reclaiming saline- sodic Soils. Journal of Agricultural and Veterinary Science1(3):30-38

Al-Shaikh, A.A., G. Abdel-Nasser and A.S. Sallam,( 2009). Reuse of date palm by-products for efficient use of nitrogen fertilizer. Int. J. Soil Sci., 4: 80-92

Asadi, F., H. Shariatmadari and N. Mirghaffari, (2008): Modification of rice hull and sawdust sorptive characteristics for remove heavy metals from synthetic solutions and wastewater. J. Hazard. Mater. 154: 451-458.

Baig, S., I. Coulomb, P. Courant and P. Liechti, (1999): Treatment of landfill leachates: Lapeyrouse and satrod case studies. Ozone: Sci. Eng. J. Int. Ozone Assoc., 21: 1-22.

Basta NT, Gradwohl R, Snethen KL, Schroder JL. (2001)Chemical immobilisation of lead, zinc and cadmium in smelter-contaminated soils using biosolids and rock phosphate. J Environ Qual 30:1222-1230

Belkhiri, L., Boudoukha, A., Mouni, L. and Baouz, T. (2010): Application of Multivariate Statistical Methods and Inverse Geochemical Modeling for Characterization of ground water-A Case Study: Ain Azel Plain (Algeria). Geoderma, 159, 390-398.

Chen, S. B., Y. G. Zhu, and Y. B. Ma. (2006): The effect of grain size of rock Phosphate amendment on metal immobilization in contaminated soils. Journal of Hazardous Materials 134 (1-3): 74-79.

Gupta, R.K. and Abrol, I.P. (1990): Salt-affected soils: their reclamation and management for crop production. In: Advances in Soil Science 11, 223288, (Lal, R. and Steward, B.A. Eds.). SpringerVerlag, New York.
Klute, A. ed. (1986): Methods of Soil Analysis. Part 1: Physical and Mineralogical methods. (2nded). Agron. Madison, Wisconsin.,USA. No.9: 210-233.

Knox AS, Seaman JC, Mench MJ, Vangronsveld J (2000): Remediation of metal andradionuclidescontaminated soils by in situ stabilization techniques. In: Iskandar IK(ed) Environmental Restoration of Metals-Contaminated Soils. Lewis, New York, pp 21-60.

Malak,A.H.R (1995): Studies on the pollution of the agriculture environment in Egypt.Ph.D. Thesis faculty of agriculture Cario Univ., Egypt.

Mourid, Sherine Shehata. (2014): Effect of calcium carbonate content on Potential toxic heavy metals adsorption in calcareous Soils 3 (2): 141-49.

Page. A.L.;Miller,R.H and Keeney,D.R(ed) .(1982): Methods of Soil Analysis.:Part-2: Chemical and Microbiological properties "(2Ed.ed).Amer. Soil Sci. Soc. Madison, Wiscensin, USA.

Raviv, M., J.H. Lieth, D.W. Burger and R. Wallach. (2001): Optimization of transpiration and potential growth rates of 'Kardinal' rose with respect to root-zone physical properties. J. Am. Soc. Hortic. Sci., 126: 638-643.

Saxena, Sona, and S F D'Souza. (2005): Heavy metal pollution abatement using rock phosphate mineral. BARC Newsl. 261: 94-99.

Soltanpour, P.N., and A.P. Schwab (1977): A new soil test for the extraction of micro and macronutrients in alkaline soils. Commun. Soil Sci. Plant Anal. 8:195-207

Steel, R. G. D. and J. H. Torrie (1980) Principle and Procedures at Statistices, A biometrical Approach. $2^{\text {nd }}$ Ed. Mc Grow- Hill Book Company.

Suarez, D.L., Rhoades, J.D., Lavado, R., and Griee, C.M. (1984): Effect of $\mathrm{pH}$ on saturated hydraulic conductivity and soil dispersion. Soil Sci. Soc. Am. J. 48,50-55.

Suzuki T, Ishigaki K, Miyake M. (1984): Synthetic Hydroxyapatites as Inorganic Cation Exchangers. J Chem Soc Farady Trans; 80:3157 -3165.

\footnotetext{
تأثير بعض محسنات التربة على تحرك أيونات بعض الفلزات الثقيلة فى تربة ملوثية

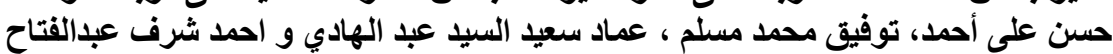

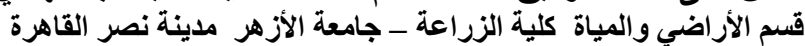

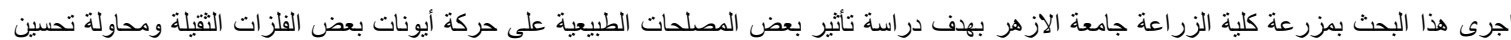

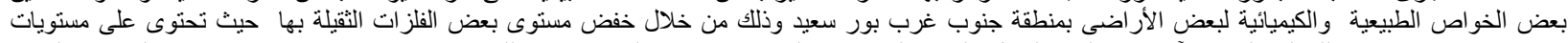

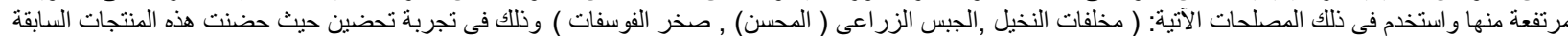

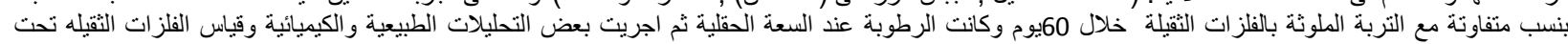

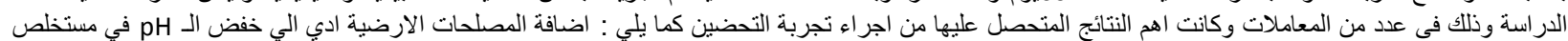

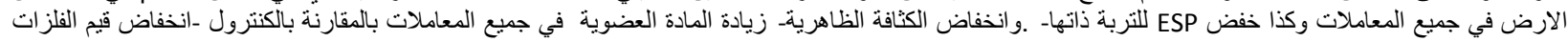

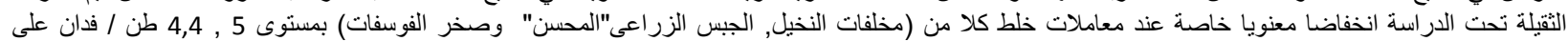

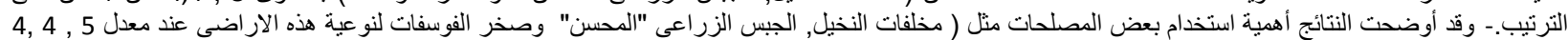
طن/فدان على الترتيب وذللك لتقليل حركة وتيسر أيونات الفلز ات الثيب الثقلة في التربة الملوثة وتحسين بعض الخو اصل الطبيعية والكيميائية وبالتالى زيادة الانتاج.
} 